\title{
Inhibitory effects of pentamidine analogues on protein biosynthesis in vitro ${ }^{\star}$
}

\author{
Krzysztof Bielawski $^{1 凶}$, Anna Galicka ${ }^{2}$, Anna Bielawska $^{1}$ and Krystyna Średzińska ${ }^{2}$ \\ ${ }^{1}$ Department of Medicinal Chemistry and Drug Technology; ${ }^{2}$ Department of General and Organic \\ Chemistry, Institute of Chemistry, Medical Academy of Biatystok, 15-230 Biatystok 8, Poland
}

Received: 25 October, 1999

Key words: amidine, DAPI, protein synthesis in vitro, elongation factors

\begin{abstract}
Pentamidine despite its rather high toxicity, is currently in clinical use. For development of new drugs of this type it is important to know the mechanism of their action. Two new amidines (I and II) and 4',6-diamidino-2-phenylindole (DAPI) were found in preliminary experiments to inhibit protein synthesis in vitro in the cell-free rat liver system. The three compounds differed in the precise mode of action. The inhibitory effect of $I$ on the activity of the eukaryotic elongation factor eEF-2 and ribosomes seems to suggest that the binding site of eEF-2 on the ribosome was blocked by this compound. eEF-2 has been identified as the primary target of II and eEF-1 as the primary target of DAPI in the system studied.
\end{abstract}

The amidines related to pentamidine show diverse pharmacological activities [1-3]. In particular, pentamidine is currently in widespread clinical use for treatment of Pneumocystis carinii pneumonia (PCP) in patients with acquired immunodeficiency syndrome [4, 5]. The precise mode of action of pentamidine is unclear and its major macromolecular targets have not been identi- fied unequivocally, but there is considerable evidence for its direct interaction with the pathogenic genome [6, 7]. Biophysical [8, 9] and footprinting studies [10] have shown that the pentamidine molecule binds to AT-rich regions of duplex DNA. Molecular modelling has suggested [11, 12] that, like with drugs such as netropsin and DAPI [13, 14], it interacts via the minor groove of DNA.

\footnotetext{
$\overline{{ }^{\star}}$ Presented at the $7^{\text {th }}$ International Symposium on Molecular Aspects of Chemotherapy, September 8-11, 1999, Gdańsk, Poland.

${ }^{\otimes}$ Author for correspondence: Krzysztof Bielawski, Department of Medicinal Chemistry and Drug Technology, Medical Academy of Białystok, 15-230 Białystok 8, Poland, tel: (48 85) 742 4710, fax: (48 85) 742 4907, e-mail: kbiel@amb.ac.bialystok.pl
}

Abbreviations: DAPI, 4',6-diamidino-2-phenylindole; eEF, eukaryotic elongation factor; PCP, Pneumocytis carinii pneumonia; TMS, tetramethylsilane. 
The mode of antimicrobial action of these dicationic molecules has been ascribed to their selective binding to the minor groove of DNA at AT-rich sites and their ability to selectively interfere with the normal functioning of the pathogen topoisomerases [5]. The lack of quantitative correlation between DNA binding by those molecules and their antimicrobial activity against all the organisms studied, can be explained by DNA binding being only the first step in a multistep process. The precise toxicity, hypotension and sterile abscesses at the injection site [4]. Serious consideration should therefore be given to evaluation of the toxic potential of these compounds as part of their development for clinical use.

As part of a continued investigation to determine the mechanism of the mode of action of pentamidine analogues, new compounds I, II and the well-known agent against trypanosomes, 4',6-diamidino-2-phenylindole (DAPI) (Fig.1) were examined for their inhibitory ef-

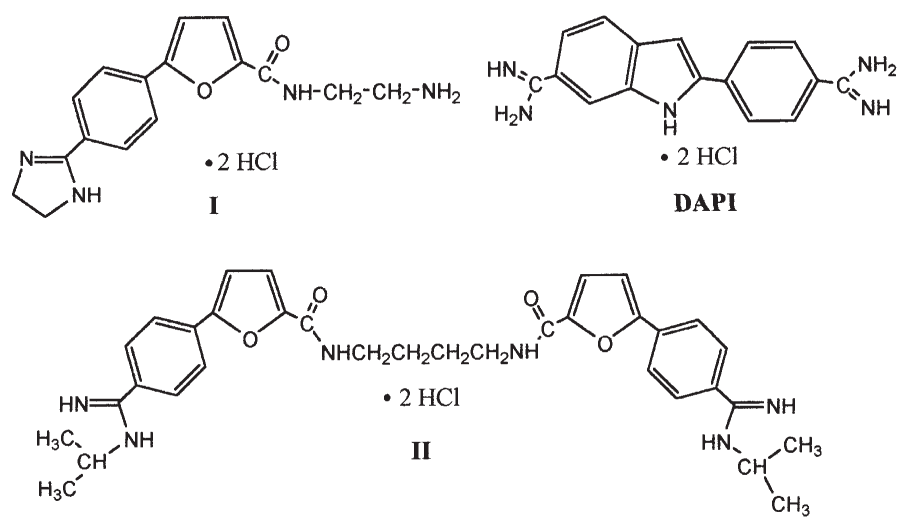

Figure 1. Structures of the pentamidine analogues.

mechanism of the inhibitory action of the aromatic amidines is currently unknown. It seems likely that a drug-DNA complex leads to inhibition, however, it is not known whether this is a consequence of competition for specific binding sites or is a result of changes in DNA conformation occurring on drug binding.

Perhaps the most serious concern in clinical application of the aromatic amidines is their toxicity. The selectivity of these compounds is limited due to the eukaryotic nature of fungi and therefore to the great degree of similarity between the fungal and mammalian protein synthesis machineries [15]. Limited oral bioavailability and both acute and chronic toxicity have slowed down the studies on development of this class of compounds. Pentamidine has seen continued use for the treatment of PCP despite an extensive list of adverse reactions that include nephrotoxicity, hepato- fects on protein synthesis in rat liver cell-free system.

\section{MATERIALS AND METHODS}

Materials. For the present study, two new pentamidine analogues, referred as compounds I and II, were synthesized in our laboratory. Preparation of compound I and II was satisfactorily achieved by standard chemical transformations according to the reaction sequence shown in Figs. 1 and 2. Purity of the compounds was verified by NMR and elemental analysis.

${ }^{1} \mathrm{H}$ NMR (200 MHz) and ${ }^{13} \mathrm{C}$ NMR (50 MHz) spectra were recorded on a Bruker AC $200 \mathrm{~F}$ spectrometer, using TMS (tetramethylsilane) as an internal standard. Chemical shifts are expressed in $\sigma$ value (p.p.m.) and coupling constants are given in $J$ (Hertz). Multiplicity 


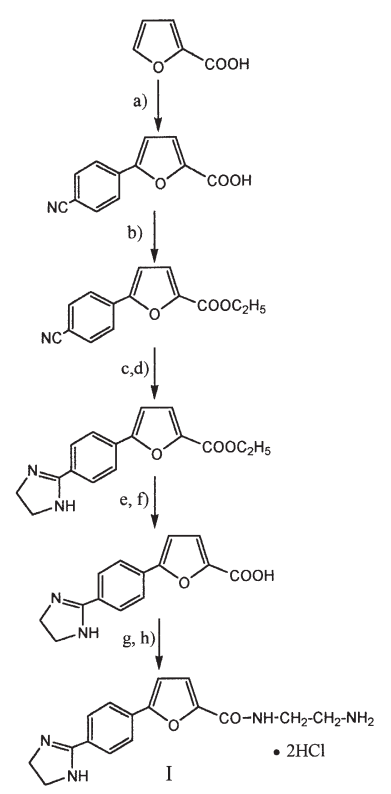

Figure 2. Synthesis of pentamidine analogue I.

Reagents and conditions: $\mathrm{a}, \mathrm{H}_{2} \mathrm{NC}_{6} \mathrm{H}_{4} \mathrm{CN}, \mathrm{NaNO}_{2}, \mathrm{HCl}$, $\mathrm{CuCl}_{2} ; \mathrm{b}, \mathrm{EtOH}, \mathrm{DCI}, \mathrm{THF} ; \mathrm{c}, \mathrm{EtOH}, \mathrm{HCl} ; \mathrm{d}$, $\mathrm{H}_{2} \mathrm{NCH}_{2} \mathrm{NH}_{2}$, EtOH; e, $\mathrm{LiOH}, \mathrm{THF} / \mathrm{H}_{2} \mathrm{O}$; f, HCl; g, $\mathrm{H}_{2} \mathrm{NCH}_{2} \mathrm{CH}_{2} \mathrm{NH}_{2}$, DCI, DMF; h, HCl.

of resonance peaks is indicated as singlet (s), doublet $(d)$, triplet $(t)$, quartet $(q)$, broad (br), or multiplet (m).

DAPI was obtained from Sigma (Steinheim, Germany).

N-(2-aminoethyl)-5-[4-(4,5-dihydro-1Himidazol-2-yl)phenyl]-2-furancarboxamide dihydrochloride (I):

m.p. (ethanol) $240-242^{\circ} \mathrm{C}$;

${ }^{1} \mathrm{H} \mathrm{NMR}\left(\mathrm{Me}_{2} \mathrm{SO}-\mathrm{d}_{6}\right) 10.77$ (br, $\left.1 \mathrm{H}\right), 8.91$ (t, $1 \mathrm{H}), 8.21(\mathrm{~d}, 4 \mathrm{H}), 8.4(\mathrm{~d}, 4 \mathrm{H}), 7.39(\mathrm{~d}, 2 \mathrm{H})$, $7.26(\mathrm{~d}, 2 \mathrm{H}), 4.02(\mathrm{~s}, 4 \mathrm{H}), 3.51(\mathrm{t}, 2 \mathrm{H}), 2.91(\mathrm{t}$, 2H). ${ }^{13} \mathrm{C}$ NMR $\left(\mathrm{Me}_{2} \mathrm{SO}_{-} \mathrm{d}_{6}\right) 164.0,157.6$, 152.5, 148.2, 134.3, 129.3, 124.5, 121.1, 115.6, 111.7, 44.3, 43.7, 38.5.

Anal. calc. for $\mathrm{C}_{16} \mathrm{H}_{18} \mathrm{~N}_{4} \mathrm{O}_{2} \cdot 2 \mathrm{HCl} \cdot \mathrm{H}_{2} \mathrm{O}$ (389): C, 49.36; H, 5.65; N, 14.39; found: C, 49.51; H, 5.69; N, 14.51 .

1,4-Bis[2-[5-(4-[(N-isopropyl)amidinophenyl)furyl]-2-carboxamido]lbutane dihydrochloride (II):

m.p. (ethanol) $232-234^{\circ} \mathrm{C}$;

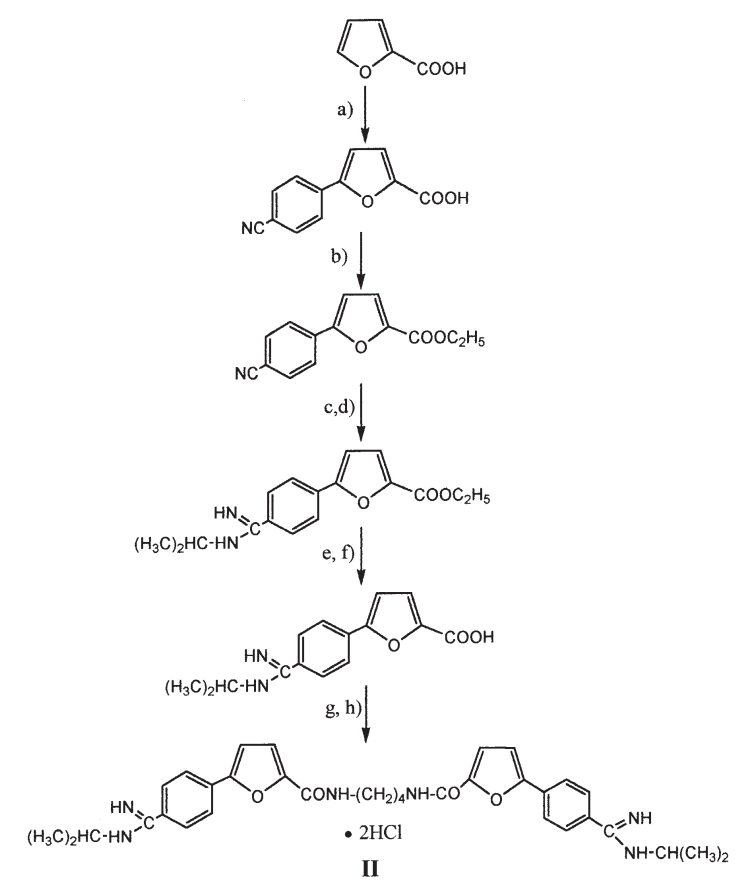

Figure 3. Synthesis of pentamidine analogue II.

Reagents and conditions: $\mathrm{a}, \mathrm{H}_{2} \mathrm{NC}_{6} \mathrm{H}_{4} \mathrm{CN}, \mathrm{NaNO}_{2}, \mathrm{HCl}$, $\mathrm{CuCl}_{2} ; \mathrm{b}, \mathrm{EtOH}, \mathrm{DCI}, \mathrm{THF} ; \mathrm{c}, \mathrm{EtOH}, \mathrm{HCl}, \mathrm{HCl}$; d, $\mathrm{CH}\left(\mathrm{CH}_{3}\right)_{2} \mathrm{NH}_{2}$, EtOH; e, $\mathrm{LiOH}, \mathrm{THF} / \mathrm{H}_{2} \mathrm{O}$; f, $\mathrm{HCl}$; g, $\mathrm{H}_{2} \mathrm{~N}\left(\mathrm{CH}_{2}\right)_{4} \mathrm{NH}_{2}$, DCI, DMF; h, HCl.

${ }^{1} \mathrm{H} \mathrm{NMR} \mathrm{( \textrm {Me } _ { 2 } \mathrm { SO } - \mathrm { d } _ { 6 } )} 9.70(\mathrm{br}, 2 \mathrm{H}), 9.56$ (br, $2 \mathrm{H}), 9.25$ (br, $2 \mathrm{H}), 8.95(\mathrm{t}, 2 \mathrm{H}), 8.12(\mathrm{~d}, 4 \mathrm{H})$, $7.94(\mathrm{~d}, 4 \mathrm{H}), 7.33(\mathrm{~d}, 2 \mathrm{H}), 7.20(\mathrm{~d}, 2 \mathrm{H}), 4.14$ (m, 2H), $3.33(\mathrm{~m}, 4 \mathrm{H}), 1.81(\mathrm{t}, 2 \mathrm{H}), 1.58(\mathrm{t}$, $4 \mathrm{H}), 1.30(\mathrm{~d}, 12 \mathrm{H}) .{ }^{13} \mathrm{C} \mathrm{NMR}\left(\mathrm{Me}_{2} \mathrm{SO}-\mathrm{d}_{6}\right)$ 161.1, 157.3, 152.5, 148.3, 134.0, 128.8, 127.6, 124.3, 115.4, 110.3, 45.1, 38.2, 26.8, 21.2.

Anal. calc. for $\mathrm{C}_{34} \mathrm{H}_{40} \mathrm{~N}_{6} \mathrm{O}_{4} \cdot 2 \mathrm{HCl} \cdot 3 \mathrm{H}_{2} \mathrm{O}$ (723): C, 56.43; H, 6.64; N, 11.62; found: C, $56.31 ; \mathrm{H}, 6.69 ; \mathrm{N}, 12.51$.

Protein synthesis in vitro. The cell-free system, ribosomes, $\left[{ }^{14} \mathrm{C}\right]$ leucyl-tRNA and the elongation factors from livers of male Wistar rats (200-250 g body mass) were prepared according to the methods previously described [16-18]. Protein synthesis in the cell-free system was examined by measuring the level of incorporation of $\left[{ }^{14} \mathrm{C}\right]$ leucine into trichloroacetic acid-precipitable material [16].

Effect of compounds I, II and DAPI on the activity of ribosomes. A ribosome suspension, $0.1 \mathrm{ml}$ (about $2 \mathrm{mg}$ ), was incubated 
Table 1. The effect of compounds I, II and DAPI on $\left[{ }^{14} \mathrm{C}\right]$ leucine incorporation into proteins in a cell-free system of rat liver

\begin{tabular}{lcccccccccccc}
\hline Pentamidine analogues & \multicolumn{4}{c}{ Compound I } & \multicolumn{4}{c}{ Compound II } & \multicolumn{4}{c}{ DAPI } \\
\hline$\mu \mathrm{g} / \mathrm{ml}$ & 0 & 12.5 & 25 & 50 & 0 & 12.5 & 25 & 50 & 0 & 12.5 & 25 & 50 \\
${ }^{14}$ C]Leucine incorporated & 618 & 446 & 339 & 22 & 618 & 370 & 154 & 10 & 618 & 396 & 192 & 0 \\
(c.p.m.) & & & & & & & & & & & & \\
Inhibitory effect (\%) & 0.0 & 27.8 & 45.1 & 96.4 & 0.0 & 40.1 & 75.1 & 98.4 & 0.0 & 36.0 & 69.0 & 100 \\
\hline
\end{tabular}

* Results are the means of three independent experiments performed in duplicate. Refer to Methods for test procedures.

at $37^{\circ} \mathrm{C}$ for $30 \mathrm{~min}$ with $200 \mu \mathrm{g}$ I, II or DAPI. At the same time, $0.1 \mathrm{ml}$ of ribosome suspension and $1 \mathrm{ml}$ of $0.05 \mathrm{M}$ Tris/HCl buffer, $\mathrm{pH}$ 8.0, as blank, were incubated. Both samples were layered on a sucrose gradient consisting of two layers: of $3.5 \mathrm{ml} 1 \mathrm{M}$ sucrose and $3.5 \mathrm{ml}$ $0.5 \mathrm{M}$ sucrose, then centrifuged for $2.5 \mathrm{~h}$ at $105000 \mathrm{~g}$. The ribosome pellet was washed and resuspended in $0.2 \mathrm{ml} 0.05 \mathrm{M}$ Tris $/ \mathrm{HCl}$ buffer, $\mathrm{pH}$ 7.4, containing $0.35 \mathrm{M}$ sucrose and $0.004 \mathrm{M} \mathrm{MgCl}_{2}$. The activity of ribosomes was examined by incorporation of $\left[{ }^{14} \mathrm{C}\right]$ leucine into protein [16].

Effect of compounds I, II and DAPI on the activity of the elongation factors. The elongation factors eEF-1 or eEF-2 were preincubated at $37^{\circ} \mathrm{C}$ for $20 \mathrm{~min}$, with 10,20

\section{RESULTS AND DISCUSSION}

Compounds I, II and DAPI were tested for their ability to inhibit protein synthesis in rat liver cell-free system. The new compound II belongs to the category of elongated minor groove binders. Such molecules are expected to exhibit greater selectivity [14] as, on binding to DNA, they occupy $6-8$ base pairs and not, like DAPI, 3-4 base pairs; unfortunately, most of them are strongly toxic in vivo [19]. The compounds I, II and DAPI at the concentration of $50 \mu \mathrm{g} / \mathrm{ml}$ caused total inhibition of $\left[{ }^{14} \mathrm{C}\right]$ leucine incorporation into proteins (Table 1). Generally, there is a good correlation between inhibition of whole-cell growth and cell-free protein synthesis, and any differ-

Table 2. Effect of compounds I, II and DAPI on the activity of ribosomes*

\begin{tabular}{cccccccc}
\hline \multirow{2}{*}{ Ribosome } & $\begin{array}{c}\text { Without inhibitory } \\
\text { solution }\end{array}$ & \multicolumn{5}{c}{ Inhibitory effect of } \\
\cline { 3 - 8 }$(\mu \mathrm{g} / \mathrm{ml})$ & c.p.m. & c.p.m. & $(\%)$ & c.p.m. & $(\%)$ & c.p.m. & (\%) \\
200 & 235 & 0 & 100 & 101 & 57 & 92 & 61 \\
300 & 363 & 0 & 100 & 189 & 48 & 182 & 50 \\
400 & 504 & 0 & 100 & 348 & 31 & 343 & 32 \\
500 & 772 & 154 & 80 & 695 & 10 & 556 & 28 \\
\hline
\end{tabular}

*Compounds I, II or DAPI (200 $\mu \mathrm{g})$ were dissolved in $0.05 \mathrm{M}$ Tris/HCl buffer at concentration of $100 \mathrm{mg} / \mathrm{ml}$. Refer to Methods for test procedures. Results are the means of three independent experiments performed in duplicate.

and $40 \mu \mathrm{g}$ of I, II and DAPI, respectively. Activity of eEF-2 was assayed in the total mixture for the elongation reaction as [14C]leucine incorporation into protein as described previously [13]. ences may be indicative of differences in the uptake or in the intracellular stability of these compounds.

In order to gain more knowledge about the precise mechanism by which these com- 

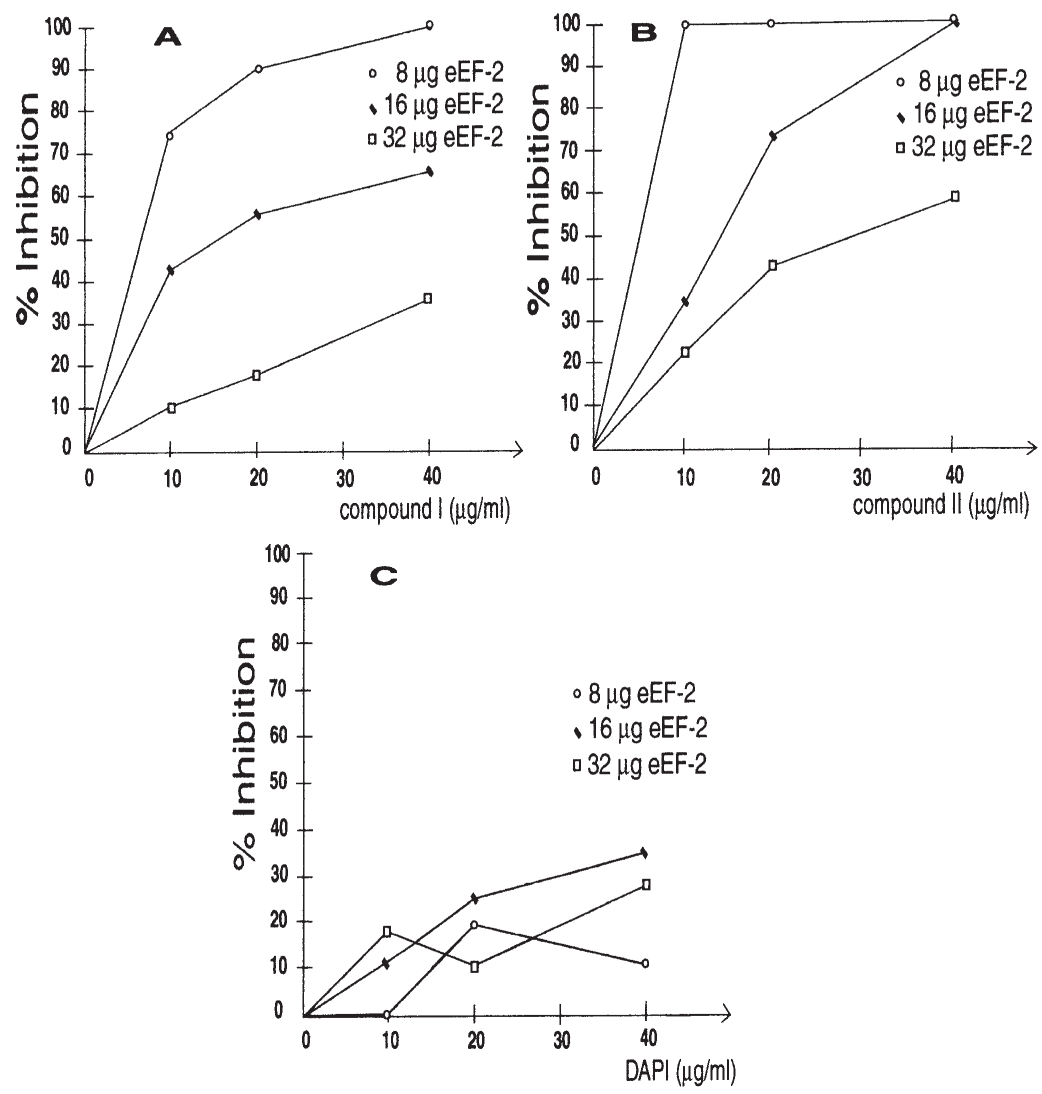

Figure 4. The effect of compounds I, II and DAPI on eEF-2 activity in the total elongation system.

*eEF-2 activity was tested by $\left[{ }^{14} \mathrm{C}\right]$ leucine incorporation into proteins in the total elongation system, with increasing amount of eEF-2, but stable amounts of eEF-1. Refer to Methods for test procedures.

pounds inhibit the protein synthesis elongation cycle, the cell-free system from rats was split into ribosomes and the protein synthesis elongation factors (eEF-1 and eEF-2). They were then used to identify whether the primary site of action of the compounds studied was the ribosome or a soluble factor.

The activity of ribosome was much more affected by compound I than by compound II (Table 2). The inhibition by compound II and DAPI was not so significant, especially at higher concentrations of ribosomes (400 and $500 \mathrm{mg} / \mathrm{ml}$ ). Although this result is not conclusive, it suggests that protein synthesis is inhibited by compound $\mathbf{I}$ in a different manner than by II and DAPI. This leads us to the conclusion that the ribosome is not the primary target of II and DAPI, and thus they cannot be treated as inhibitors of peptide bond formation. Moreover, since the aminoacyl-tRNA synthetase activity is not affected by those compounds (not shown) we can infer that one of the two elongation factors might be the target of II and DAPI.

The effects of compounds I, II and DAPI on the elongation factors eEF-1 and eEF-2 activities were verified in the following experiments. I and II inhibited eEF-2 activity (Figs. $4 \mathrm{~A}$ and $4 \mathrm{~B}$ ). The molecules of I and II appeared to affect marginally the eEF-1 activity (Figs. 5A and 5B). In contrast, DAPI showed the opposite pattern, with a markedly lower potency with respect to the elongation factor eEF-2 and $100 \%$ inhibition of the activity of eEF-1 at the concentration of $40 \mu \mathrm{g} / \mathrm{ml}$ (Fig. 5C). 

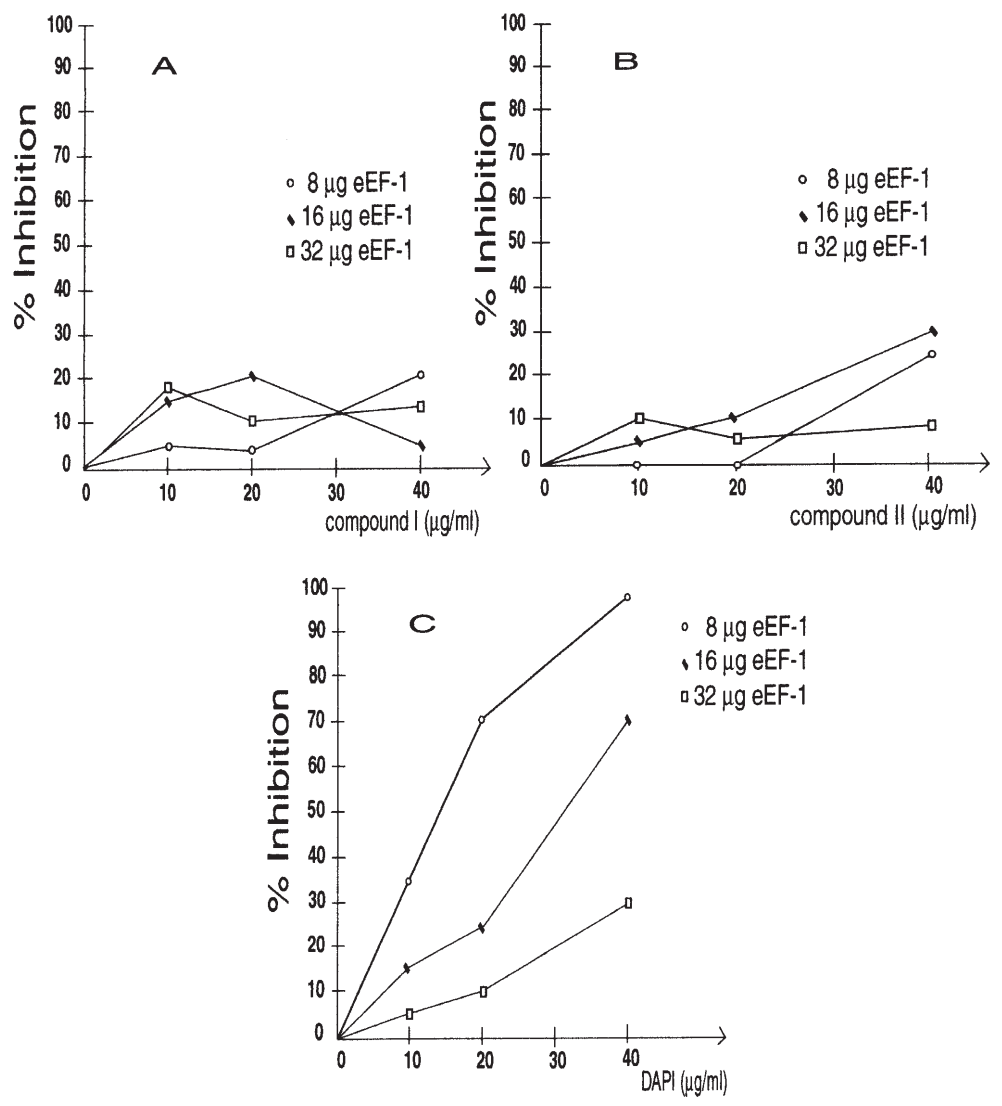

Figure 5. The effect of compounds I, II or DAPI on eEF-1 activity in the total elongation system.

*eEF-2 activity was tested by $\left[{ }^{14} \mathrm{C}\right]$ leucine incorporation into proteins in the total elongation system, with increasing amount of eEF-1, but stable amounts of eEF-2. Refer to Methods for test procedures.

Our preliminary experiments have shown that even small amounts of compounds I, II and DAPI inhibit markedly [ $\left.{ }^{14} \mathrm{C}\right]$ leucine incorporation into proteins in the cell-free rat liver system. Since all three contain the benzamidine group as the main part of the molecule, it was reasonable to assume that they all aim at the same target. However, substitutions may give rise to differences in the interactions with specific residues at the binding site of the targeted proteins. This, combined with differences in the target structure among the tested components of the rat liver cell-free system, might explain the diversity of the results obtained. It may be concluded that I, II and DAPI inhibit protein biosynthesis in vitro in the cell-free rat liver system, but they differ in the precise mode of action.
The most marked direct inhibitory effect of $\mathbf{I}$ on the ribosome and eEF-2 activity seems to suggest that the binding site of eEF-2 on the ribosome is blocked by this compound. The interaction between $\mathbf{I}$ and its target is greatly favored by the presence of ribosomes. It is well known that interaction with ribosomes promotes conformational changes on the two elongation factors and that these changes lead to the appearance of a latent enzyme activity, i.e., GTPase for EF- $1 \alpha$ and EF-2 and ATPase [20, 21].

Our results indicate that the inhibition of protein synthesis by II and DAPI is dependent on the nonribosomal fraction more than on the ribosomes. Preliminary studies performed to elucidate the mode of action of II and DAPI have shown that the putative target 
of these compounds are the protein synthesis elongation factors. The factor eEF-2 has been identified as the primary target of compound II, and the factor eEF-1, as the primary target of DAPI. Further studies are required to confirm directly our conclusions. EF-2, as well as its prokaryotic counterpart, EF-G, promotes translocation, i.e., displacement of nascent peptidyl-tRNA from the A site to the $\mathrm{P}$ site and movement of the ribosome along the mRNA; this is accompanied by a conformational change in the ribosome from the pretranslocational to the posttranslocational state [22]. According to recent findings [23], GTP hydrolysis catalyzed by an elongation factor might provide the energy needed for the process. EF-2 is a highly conserved protein $(85 \%$ homology and $66 \%$ identity between human EF-2 and Saccharomyces cerevisiae EF-2) [24]. It has been shown both for EF-G and for EF-2 from different sources that this protein is able to display different conformations depending on whether it is alone or interacting with GTP, GDP, or a ribosome in either the pre- or the posttranslocational state $[25,26]$. This conformational flexibility determines its biological properties and may explain how such a conserved protein can be the target of II. There is a clear need for further studies on the structure of DAPI, I and II complexes with the ribosome and the protein synthesis elongation factors.

\section{R E F E R E N C E S}

1. Schoenbach, E.B. \& Greenspan, E.M. (1948) The pharmacology, mode of action and therapeutic potentialities of stilbamidine, pentamidine, propamidine and other aromatic diamidines - a review. Medicine 27, 327-377.

2. Blagburn, B.L., Sunderman, C.A., Lindsay, D.S., Hall, J.E. \& Tidwell, R.R. (1991) Inhibition of Cryptosporidium parvum in neonatal Hsd:(ICR)BR Swiss mice by polyether ionophores and aromatic amidines. Antimicrob. Agents Chemother. 35, 1520-1523.
3. Bell, C.A., Hall, E.D., Kyle, E., Grogl, M., Ohemeng, K.A., Allen, M.A. \& Tidwell, R.R. (1990) Structure-activity relationships of analogs of pentamidine against Plasmodium falciparvum and Leishmania mexicana amazonensis. Antimicrob. Agents Chemother. 34, 1381-1386.

4. Wispelwey, B. \& Pearson, R.D. (1991) Pentamidine: A review. Infect. Control Hosp. Epidemiol. 12, 375-381.

5. Gazzard, B.G. (1989) Pneumocystis carinii pneumonia and its treatment in patients with AIDS. J. Antimicrob. Chemother. 23, 67-75.

6. Cory, M., Tidwell, R.R. \& Fairley, T.A. (1992) Structure and DNA binding activity of analogues of 1,5-bis(4-amidinophenoxy)pentane (pentamidine). J. Med. Chem. 35, 431-438.

7. Shapiro, T.A. \& Englund, P.T. (1990) Selective cleavage of kinetoplast DNA minicircles promoted by antityrypanosomal drugs. Proc. Natl. Acad. Sci. U.S.A. 87, 950-954.

8. Zimmer, C. \& Wähnert, U. (1986) Non-intercalating DNA-binding ligands: Specificity of the interaction and their use as tools in biophysical, biochemical and biological investigations of the genetic material. Prog. Biophys. Mol. Biol. 47, 31-112.

9. Luck, G., Zimmer, C. \& Schweizer, D. (1988) DNA binding studies of the nonintercalative ligand pentamidine: $\mathrm{dA} \cdot \mathrm{dT}$ base-pair preference. Stud. Biophys. 125, 107-119.

10. Fox, K.R., Sansom, C.E. \& Stevens, M.F.G. (1990) Footprinting studies on the sequence-selective binding of pentamidine to DNA. FEBS Lett. 266, 150-154.

11. Lowe, P.R., Sansom, C.E., Schwalbe, C.H. \& Stevens, M.F.G. (1989) Crystal structure and molecular modelling of the antimicrobial drug pentamidine. J. Chem. Soc., Chem. Commun. 1164-1165.

12. Sansom, C.E., Laughton, C.A., Neidle, S., Schwalbe, C.H. \& Stevens, M.F.G. (1990) 
Structural studies on bioactive compounds. XIV. Molecular modelling of the interactions between pentamidine and DNA. Anti-Cancer Drug Design 5, 243-248.

13. Kopka, M.L., Yoon, C., Goodsell, D., Pjura, P. \& Dickerson, R.E. (1985) Binding of an antitumour drug to DNA netropsin and CGCGAATTBrCGCG. J. Mol. Biol. 183, 553-563.

14. Neidle, S. (1997) Crystallographic insights into DNA minor groove recognition by drugs. Biopolymers 44, 105-121.

15. Moldave, K. (1985) Eukaryotic protein synthesis. Annu. Rev. Biochem. 54, 1109-1149.

16. Gałasiński, W. \& Moldave, K. (1969) Purification of aminoacyltransferase II (translocation factor) from rat liver. J. Biol. Chem. 244, 6527-6532.

17. Jabłonowska, K., Kopacz-Jodczyk, T., Niedźwiecka, J. \& Gałasiński, W. (1983) Isolation and characterization of elongation factor EF-2 from Guerin tumour. Acta Biochim. Polon. 30, 381-388.

18. Gajko, A., Gałasiński, W. \& Gindzieński, A. (1994) Multiformity of elongation factor eEF-2 isolated from rat liver cells. Biochem. Biophys. Res. Commun. 202, 844-849.

19. Fairley, T.A., Tidwell, R.R., Donkor, A., Naiman, N.A., Ohemeng, K.A., Bentley, J.A. \& Cory, M. (1993) Structure, DNA minor groove binding and base pair specificity of alkyl- and aryl-linked bis(amidinobenzimidazoles) and bis(amidinoindoles). J. Med. Chem. 36, 1746-1753.

20. Proud, C.G. (1994) Peptide-chain elongation in eukaryotes. Mol. Biol. Rep. 19, 161-170.

21. Rug, B., Rattan, I.S., Clark, B.F.C. \& Merrick, W.C. (1990) Eukaryotic protein elongation factors. Trends Biochem. Sci. 15, 420-424.

22. Nierhaus, K.H. (1996) An elongation factor turn-on. Nature 379, 491-492.

23. Rodnina, M.V., Savelsbergh, A., Katunin, V. \& Wintermeyer, W. (1997) Hydrolysis of GTP by elongation factor $\mathrm{G}$ drives tRNA movement on the ribosome. Nature 385, 37-41.

24. Perenthesis, J.P., Phan, L.W., Gleason, H., LaPorte, D.C, Livingston, D.M. \& Bodley, J.W. (1992) Saccharomyces cerevisiae elongation factor 2. Genetic cloning, characterization of expression and G-domain modeling. J. Biol. Chem. 267, 1190-1197.

25. Nilsson, L. \& Nygard, O. (1985) Localization of the sites of ADP-ribosylation and GTP binding in the eukaryotic elongation factor EF-2. Eur. J. Biochem. 148, 299-304.

26. Nygard, O. \& Nilsson, L. (1989) Characterization of the ribosomal properties required for formation of a GTPase active complex with the eukaryotic elongation factor 2. Eur. J. Biochem. 179, 603-608. 